\title{
Global Wind Energy Market, Industry and Economic Impacts
}

\author{
Wagner Sousa de Oliveira ${ }^{1} \&$ Antonio Jorge Fernandes ${ }^{1}$ \\ ${ }^{1}$ Department of Economics, Management and Industrial Engineering, University of Aveiro, Portugal \\ Correspondence: Wagner Sousa de Oliveira, Department of Economics, Management and Industrial Engineering, \\ University of Aveiro, Portugal. E-mail: wsoliveira76@gmail.com
}

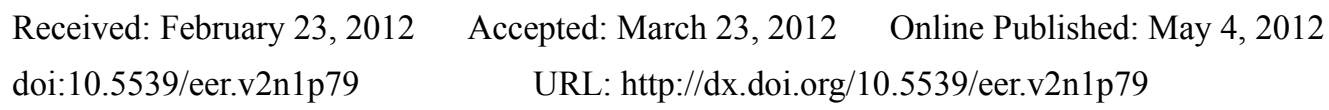

The research is financed by Foundation for Research and Technological and Scientific Development of Maranhão (FAPEMA) - Brazil and Economics Department of University of Aveiro.

\begin{abstract}
This paper presents the global status of wind energy in order to establish a context for understanding the contemporary wind energy industry. It is discussed wind resources worldwide with the global wind distribution and mains concerns and how wind resources worldwide are spread globally. The world wind energy market outlook is shown; especially emphasis is given on global wind energy market by production side, wind energy converters manufacturers and economic impacts from wind energy industry on economy which it is devoted special attention to the job creation by wind energy industry.
\end{abstract}

Keywords: wind energy, market, industry, economic impacts, jobs

\section{Introduction}

The development of wind energy in many regions of the world faces the lack of reliable and detailed wind resource data in that site. Availability of these data is necessary for public authorities and other economic agents involved to identify wind power generation potential and to promote rightly actions on that information. To overcome this difficulty, the National Renewable Energy Laboratory (NREL) and other organizations have, since the last five years developed new methods and approaches to more accurately assess the wind resource and produce detailed high-resolution $(1-\mathrm{km})$ wind maps for essentially anywhere in the globe. The NREL methodology for creating large-area wind resource maps is force-task for unifying global terrain and climatic data sets, Geographical Information Systems (GIS) technology, and analytical and computational techniques (Elliott, 2002).

The modeling and wind resource predictions that do not need to rely on country-supplied data were permitted by the global data sets and analytical tools at NREL. In many regions of the globe, reliable surface wind data are sparse and often not available for areas of interest for producing electricity by wind technology. However, the use of weather balloon and satellite-derived wind data with computer mapping system enables NREL to create wind resource maps with reliable information even if high-quality surface wind data are not available yet. Wherever available, reliable surface wind data are useful in providing field truth verification of the model predictions.

When we analyze different technologies of power generation including fossil fuel or renewable energies the main concern the fuel consumed or avoided. What is the best technology of power generation (of electricity or heating)? Are the power plants in the right places? How much is it available for electricity demand? What is the production cost for each $\mathrm{kWh}$ of electricity produced? What emissions does it have for each $\mathrm{kWh}$ of electricity produced? How much residue does it leave? For wind power technology, the wind resource is "free of fuel" and "free of charge" and these questions are as relevant as they are for any other source. As wind is "free" and "green" so the concern about fuel makes no sense. Questions about wind resources, however, are very important and essential for wind technology development. When we talk on a global scale, it is not difficult to find many studies about the enormity of the wind resource, and how it could be theoretically used for facing the global electricity demand in several times over. For example the collaboration by researchers at Harvard University in the United States and VTT in Finland that concluded that "a network of land-based, $2.5 \mathrm{MW}$ turbines, restricted to non-forested, ice-free and nonurban areas, operating at as little as $20 \%$ of their rated capacity could supply more than 40 times current worldwide consumption of electricity" (Lu, McElroy, \& Kiviluoma, 2008). 
A comprehensive study by researchers from Stanford University's Global Climate and Energy Project focuses its conclusions on five years of data from the US National Climatic Data Center. Using an extensive set of surface and balloon measurements, they concluded that $13 \%$ of the sites tested had a good wind resource (Class (Note 1) 3) at 80 meters off the ground, and using one in five of these sites for power generation would allow wind energy to meet the world's electricity demand (considering the data of year 2000) seven times over (Archer \& Jacobson, 2005). In the same objective, an earlier study in 2003 by the German Advisory Council on Global Change calculated that the global technical potential for electricity production from both onshore and offshore wind technologies was 270,000 TWh per year. Considering $10 \%$ to $15 \%$ of this was executable in a sustainable manner, the resulting 39,000 TWh would meet more than double the current global electricity demand. A literature search shows up numerous similar studies with broadly similar conclusions (GACGC, 2004). According to Rosa (2009, p. 5) "30\% of the 173,000 TW of solar radiation incident on Earth is reflected back into space as the planetary albedo (Note 2). Of the 121,000TW that reach the surface, 3\% (3600TW) are converted into wind energy, and 35\% of this is dissipated in the lower $1 \mathrm{~km}$ of the atmosphere. This corresponds to $1200 \mathrm{TW}$. Since humanity at present uses only some 15TW, it would appear that wind energy alone would be ample to satisfy all of our energy needs".

The studies have different results, because it depends on its assumptions used. For estimation of wind power potential is necessary to make assumptions about the size, capacity factor and rated power of the turbines used, which varies from study to study. We must highlight the higher the wind turbine is working, the better the wind resource is. Further, higher wind turbines or wind farms are less to be affected by turbulence caused by natural topography, surface roughness or other effects of orography (Note 3). Even more, the technology evolution can not only increase the capacity factor of wind turbines, but also the range of wind speeds in which they can work, thus broadening the range of sites at which they can be installed.

Another variable concerns assumptions about the land areas on which wind turbines can be deployed. While most studies will focus on conservation areas, forests and urban sites, some types of agricultural land such are easily compatible with wind farms installations without constraining the overall wind potential of a region. In the case of offshore wind resources the methodologies for evaluation of its availability also differ in terms of assumptions used. An assumption needs to made concerning the areas in which wind farms can be built, both for technical reasons (maximum technical/economical distance to shore, water depth etc.), as well as taking into account environmental and regulatory limitations (nature reserve areas, shipping lanes, minimum distance to shore, etc.). Some new configurations that deploy turbines on floating structures and are thus suitable for use in deep water are at a preliminary stage of test deployment (Bilgili, Yasar, \& Simsek, 2011). These could dramatically increase the technically usable fraction of the offshore wind potential. Evidence from a large number of studies into the world's wind resources suggests that there is no shortage of suitable sites for wind power development. However, it is worth noting that the rate of deployment of wind power in each county has largely been dependent on political will rather than resource criteria. Germany has a lower wind potential than many other European countries, yet its favorable political climate has led to fast and large-scale deployment of wind power. On the other hand, there are several parts of the globe with a good wind resource - places such as Argentina, Russia and South Africa - where development of wind power has barely started (GWEC, 2011b).

The wind resources are spread globally, as we know the wind is fundamentally a form of solar energy. Wind is the result of simple air motion. It is caused by the unequal heating of the earth surface by the sun heat. Since the earth surface is made of different kinds of continents and oceans, it absorbs the sun heat at different rates, and the different temperature could cause the different pressure. The heat is distributed to the poles by ocean currents and atmospheric circulation (Maddaloni, 2005). As we can see in Figure 1, world wind map at 80m high, into a wind speed scale from 3-9 m.s ${ }^{-1}$, there are some regions on the globe (RETScreen ${ }^{\circledR}$ International Clean Energy Decision Support Centre, 2009). When it is necessary take into account the wind resources as an initial input or datum for wind farms economic evaluation, researchers as Marafia and Ashour (2003), Archer and Jacobson (2005), Arslan (2010), Ahmed (2011), Oliveira (2010b), Gökçek and Genç (2009) show that a wind speed range starting from $3 \mathrm{~m} . \mathrm{s}^{-1}$ as a minimum wind speed for wind power project gives economic returns to the investor. Wind energy projects are generally as more as financially viable in "windy" sites. This is due to the fact that the theorical power output in the current wind technology is equal to the cube of the wind speed. However, the power production profile of a wind turbine is typically more proportional to the square of the average wind speed (Manwell, McGowan, \& Rogers, 2002). 

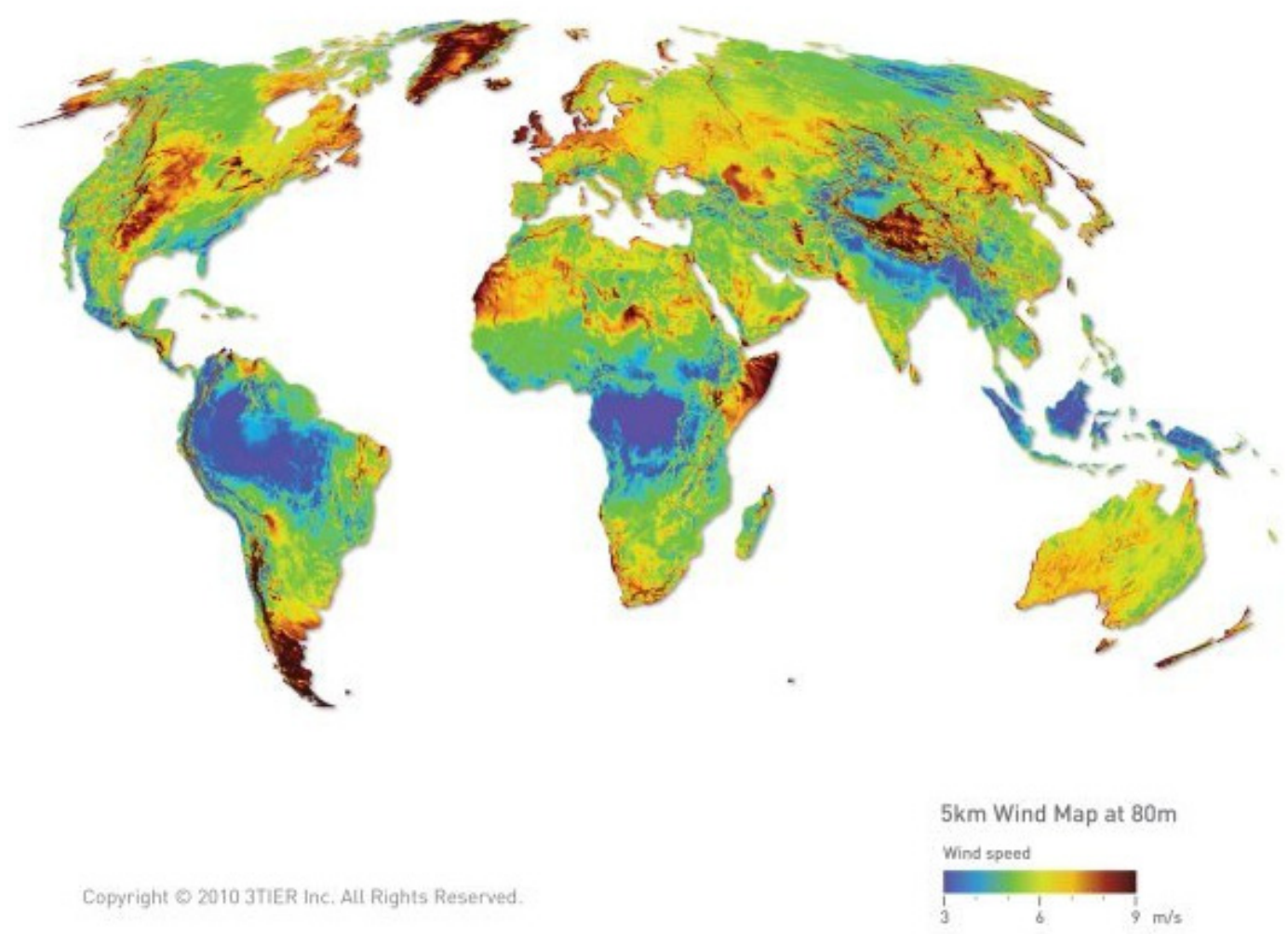

Figure 1. World wind map at $80 \mathrm{~m}$. Source: 3 TIER, Inc/REmapping the World Initiative (RETScreen ${ }^{\circledR}$ International Clean Energy Decision Support Centre, 2009)

North America and Antarctica are the best locations for electricity production by wind energy technology. But they are also very favorable to electricity production by wind energy technology in the northern Europe, especially along the North Sea, the southern tip of South America (Tierra del Fuego or Fireland) and Tasmania, in Oceania. According to Herbert et al. (2007) the theorical potential of wind energy onshore is very large $-20,000 \times 10^{9}$ to $50,000 \times 10^{9} \mathrm{kWh}$ per year in comparison with the current total annual global electricity consumption of approximately $15,000 \times 10^{9} \mathrm{kWh}$, in 2005 . Archer \& Jacobson (2005) concludes that:

1. About $13 \%$ of all stations worldwide belong to class 3 or greater (i.e., annual mean wind speed $\geq 6.9 \mathrm{~m} . \mathrm{s}^{-1}$ at $80 \mathrm{~m}$ ) and they are indicated for electricity production by wind energy technology. In addition, wind power potential in these areas studied was underestimated in comparison to other studies.

2. The wind speed average calculated at $80 \mathrm{~m}$ was $4.59 \mathrm{~m} \cdot \mathrm{s}^{-1}$ (class 1 ) when including all stations; if only stations in class 3 or higher are considered, the average was $8.44 \mathrm{~m} \cdot \mathrm{s}^{-1}$ (class 5). For comparison, the wind speed average observed at $10 \mathrm{~m}$ from all stations was $3.31 \mathrm{~m} . \mathrm{s}^{-1}$ (class1) and from class $\geq 3$ stations was $6.53 \mathrm{~m} . \mathrm{s}^{-1}$ (class 6).

3. The greatest numbers of stations in class $\geq 3$ are in Europe and North America, whereas the greatest percentages are Oceania and Antarctica, $21 \%$ and $60 \%$, respectively. Northern Europe along the North Sea, the southern tip of the South American Continent, the island of Tasmania in Australia, the Great Lakes region, the northeastern and western coasts of Canada and the United State have a strong wind power potential.

4. The wind speed was global-averaged at $80 \mathrm{~m}$ was higher during the day $\left(4.96 \mathrm{~m} \cdot \mathrm{s}^{-1}\right)$ than night $\left(4.85 \mathrm{~m} \cdot \mathrm{s}^{-1}\right)$. The average nocturnal wind speed at above $\sim 120 \mathrm{~m}$ was higher than the diurnal average.

The European Wind Energy Association (EWEA) and Greenpeace with their action for evaluation of global wind resources called "Wind Force 12" has concluded that the world's electricity production by wind energy technology considering only $10 \%$ of the Earth's land area would be available for development, which figures the double of projected world electricity demand in 2020. Addition, a larger share of the land area could be used for electricity production by wind energy technology in sparsely populated and wind-rich regions in the globe as e.g. the Great Plains of North America, northwest China, eastern Siberia, and the Patagonian region of Argentina (Brown, 2003). 
For a successful application of wind turbines is necessary the study of geographical distribution of wind resources, speeds profiles, topography and local wind flow and measurement of the wind speed are very essential in a complete and robust wind resource evaluation. The main and most direct mechanism by which global climate change could impact directly in the wind energy industry is by changing the geographic distribution due to its inter-and intra-annual variability of the wind resource available. For Pryor and Barthelmie (2010) the global climate change may change the geographic distribution of wind resources in order to the variability of wind resource in a inter or intra yearly basis and it could change as result other the conditions for wind developments. As in a traditional industry sitting, the production and distribution of its process depending on the place where the vital resources can be found, in the case of the wind energy industry, the wind resources.

\section{Global Wind Energy Market}

For Wiser and Hand (2010a) the global wind power capacity is growing fast in the last ten year, as a result, wind power has quickly become part of the mainstream in the global electricity industry. In 2007, roughly $20 \mathrm{GW}$ of new wind capacity was increased globally, yielding a cumulative total of $94 \mathrm{GW}$ (see Figure 2). Since 2000, cumulative wind capacity has grown at an average annual rhythm of $27 \%$. The vast majority of this capacity has been located on land; offshore wind capacity surpassed $1 \mathrm{GW}$ at the end of 2007, with accelerated growth expected in the future, especially in Europe. The expectations for wind power market growth in 2010 were mixed, as the low level of orders seen during the financial crisis worked their way through the system. The results of this were felt much more strongly in 2010 than in the previous year, and the overall annual market shrunk by $7 \%$ to $35.8 \mathrm{GW}$, down from $38.6 \mathrm{GW}$ in 2009. The new capacity added in 2010 is equivalent in direct investments worth EUR 47.3 billion (USD 65 billion) (GWEC, 2011c).

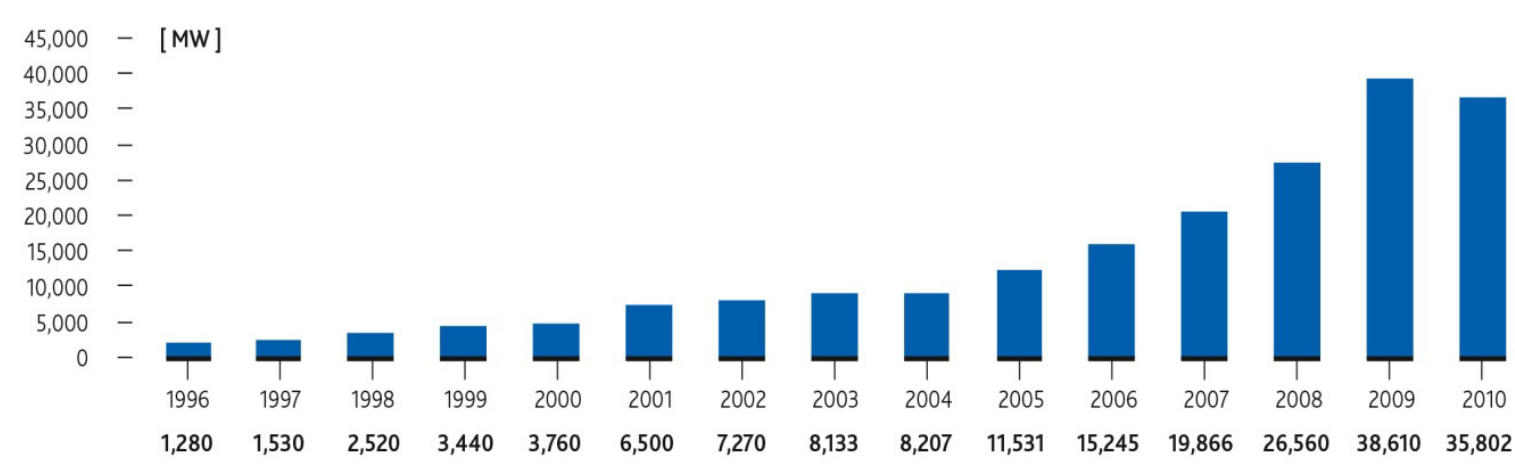

Figure 2. Global annual installed wind capacity 1996-2010

Source: Global Wind Report: Annual market update 2010 (GWEC, 2011c)

The global cumulative installed wind capacity in 1996-2010, in the year 2010, the wind capacity sums worldwide 194,390 MW, after 158,738 MW in 2009, 120,291 MW in 2008, and 93,820 MW in 2007. New wind turbines investment has declined in many parts of the globe. For the first time in more than twenty years, the market for new wind turbines was smaller in comparison with the last year and totalized an overall size of 35,802 MW, after $38,610 \mathrm{MW}$ in 2009. The recovering of the wind industry worldwide totalized 40 billion ( 55 billion US\$) in 2010, after 50 billion (70 billion US\$) in the year 2009. The decrease is impact of lower prices for wind turbines and a shift towards China. The US market installed almost 50\% less than in 2009. In the European market, new installed capacity in 2010 was $7.5 \%$ down on 2009 , despite a 50\% growth of the offshore market in countries like the UK, Denmark and Belgium, otherwise Romania, Bulgaria and Poland had a fast growth (WWEA, 2011). In December 2010 , the ten biggest countries in cumulative capacity installed of wind power were distributed as shown in Figure 3. 


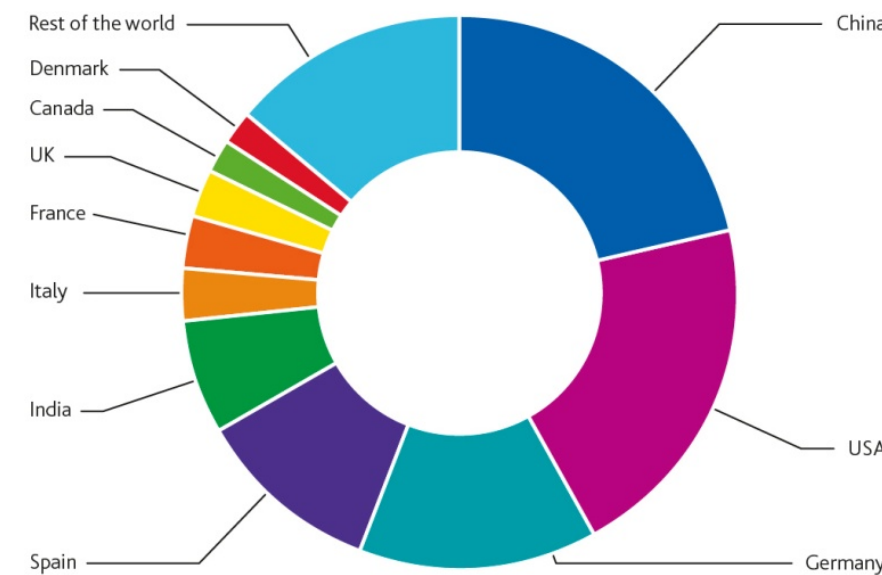

\begin{tabular}{rrr} 
Country & MW & $\%$ \\
\hline China & 42,287 & 21.8 \\
USA & 40,180 & 20.7 \\
Germany & 27,214 & 14.0 \\
Spain & 20,676 & 10.6 \\
India & 13,065 & 6.7 \\
Italy & 5,797 & 3.0 \\
France & 5,660 & 2.9 \\
UK & 5,204 & 2.7 \\
Canada & 4,009 & 2.1 \\
Denmark & 3,752 & 1.9 \\
\hline Rest of the world & 26,546 & 13.7 \\
\hline Total TOP 10 & 167,844 & $\mathbf{8 6 . 3}$ \\
\hline World Total & 194,390 & 100
\end{tabular}

Figure 3. Top 10 cumulative capacity Dec. 2010

Source: Global Wind Report: Annual market update 2010 (GWEC, 2011c)

The main markets driving growth are Asia and Europe, which installed $19 \mathrm{GW}$ and $9.9 \mathrm{GW}$ respectively in 2010. However, emerging markets in Latin America are beginning more competitive, led by Brazil and Mexico. In cumulative terms, the Latin America and Caribbean market grew by more than 53\% during 2010. China, USA, Germany and Spain lead the global wind market with a share of $67.1 \%$ which has a great impact in the global energy matrix and in their domestic economies. We could see more than half of all new wind power was increased outside of the traditional markets of Europe and North America in 2010 (GWEC, 2011c). In case of Asia, what pushes this continent forward is the continuing boom in China, with $16.5 \mathrm{GW}$ of new installations in 2010. China had at the end of $201042.3 \mathrm{GW}$ of wind power, which represents an increase of $64 \%$ in relation to the end of the year 2009 and has surpassed the US in wind power capacity. The growing Chinese wind power market has pushed forward domestic production of wind turbines and components, because of this the Chinese manufacturing industry has been increasingly mature and this fact reflects over the whole supply chain. China has become the world's largest producer of wind energy equipment and components made inside the country (see Figures 6 and 7). China started to not only satisfy domestic demand, but also meet international market. Sinovel and Goldwind had given a step ahead for entering into international markets, which is justified the world's top five wind turbine manufacturers in 2009 (GWEC, 2011a).

\subsection{Africa \& Middle East}

Wind energy could help African continent to face the lack of electricity. About a quarter of the world's population has no access to electricity, and the problem is especially acute in peri-urban and rural areas in Sub-Saharan Africa. Although Africa and Middle East has shown a great development of wind power technology, 
especially in wind power capacity in MW. We highlight Tunisia, Egypt and Morocco. When it is considered the end of 2009 and the end of 2010 , these countries has an increase in wind power capacity of $111 \%, 28 \%$ and $13 \%$, respectfully. At the end of 2010 Tunisia had installed $550 \mathrm{MW}$, Morocco $286 \mathrm{MW}$ and Tunisia $114 \mathrm{MW}$ (GWEC, 2011a). Africa and Middle East have increased 25\%, in the same period and had as wind power capacity installed about $1 \mathrm{GW}$.

2.2 Asia

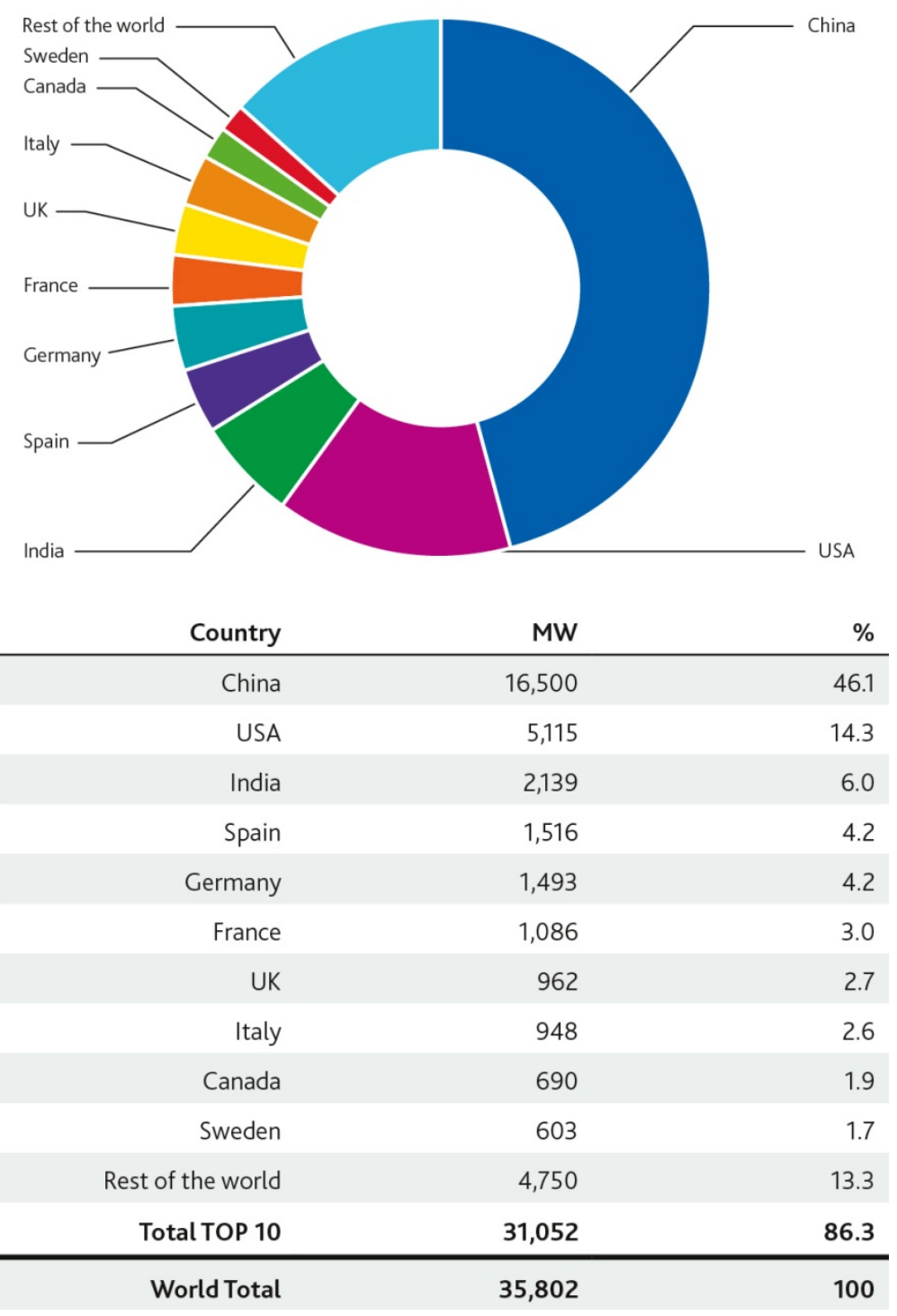

Figure 4. Top 10 new installed capacity Jan-Dec 2010

Source: Global Wind Report: Annual market update 2010 (GWEC, 2011c)

Asia in terms of wind energy has been surprising globally. According to the Global Wind Energy Council (GWEC) (2011a). Asia at the end of 2010 had installed almost $59 \mathrm{GW}(58,641 \mathrm{GW})$. China was the world's largest market in 2010 with $16.5 \mathrm{GW}$ of new capacity installed and go ahead of the USA and became the global's leading wind power country (see Figure 4). However, there are indications that only about half of the turbines in China are really in operation. Many of the wind farms are not connected to the grid because of quality problems or grid weakness, and appear to have been constructed to allow large utility companies to gain incentives in order to expand their coal-fired operations. The whole market is still heavily dominated by onshore projects. Of the total cumulative capacity only $2.1 \mathrm{GW}$ is offshore of which about $689 \mathrm{MW}$ was installed last year. Of special 
significance are the 209 MW wind farm project Horns Rev II and Germany's first offshore wind farm Alpha Ventus, with a capacity of $60 \mathrm{MW}$ (Markard \& Petersen, 2009). The Chinese market had increased its capacity from $25.8 \mathrm{GW}$ in 2009 to $42.2 \mathrm{GW}$ at the end of 2010 ; it is an increase of $64 \%$ in the same period. In the case of India, the Indian wind power market awaked and increased its capacity from $10.9 \mathrm{GW}$ in 2009 to $13.0 \mathrm{GW}$ at the end of 2010; it is an increase of $20 \%$ in the same period. In terms of new installed capacity during 2010 and comes in third position behind China and the USA (see Figure 4). Wind power accounts for $70 \%$ of this renewable installed capacity. In 2010 the official wind power potential estimates for India were revised upwards from $45 \mathrm{GW}$ to $49.1 \mathrm{GW}$ by the Centre for Wind Energy Technology (C-WET). Other Asian countries with new capacity additions in 2010 include Japan (221 MW, for a total of $2.3 \mathrm{GW}$ ), South Korea (31 MW for a total of $379 \mathrm{MW}$ ) and Taiwan (83 MW for a total of $519 \mathrm{MW}$ ). The Chinese market, in particular, now has three manufacturers among the top 10 global players and has shown potential for more new businesses. The acceptance of new wind turbines on the market depends on their suitability for international trade and the successful operation of their first projects. Most of the new players still have to prove this, particularly regarding the quality and long-term stability of turbine operations. In mid-2009, the South Korean firm Daewoo Shipbuilding \& Marine Engineering (DSME), the world's second largest shipbuilder, announced its entry into the wind energy market by acquiring DeWind for around US\$50 million. DeWind is a medium-sized wind turbine manufacturer that has installed around 570 wind turbines in the $500 \mathrm{~kW}$ to $2 \mathrm{MW}$ range (Wiese, Kleineidam, Schallenberg, Ulrich, \& Kaltschmitt, 2010). Asia has increased 48\%, in the same period and had as wind power capacity installed about $58.6 \mathrm{GW}$.

\subsection{Europe}

The Europe continent has been facing serious economics and financial problems in its EU Members States. The EU Member States have tried to reduce unemployment situation, low productivity, in other words, come back to growth road and stop economic recession. Related to wind power, reflected investment in RE technologies since decades ago, the wind power installed across Europe in 2010 reached $86 \mathrm{GW}$. This represents an increase only of 13\% compared to 2009. According to European Wind Energy Association (EWEA) (EWEA, 2012) the annual onshore market increased by over $13 \%$ compared to 2009 , while the annual offshore market grew by $51 \%$, and accounted for $9.5 \%$ of all capacity additions. In terms of total capacity installed, we must highlight Germany and Spain, at the end of 2010, with $27.2 \mathrm{GW}$ and $20.6 \mathrm{GW}$, respectively. In terms of new installations Spain was the largest market in 2010, installing $1.5 \mathrm{GW}$ followed by Germany with $1.4 \mathrm{GW}$. For Spain 2010 was a good year for wind power, and the country's wind farms produced 42.7 TWh of electricity, which figures $16.6 \%$ of total Spanish power consumption. Five out of Spain's 17 regions now host $1 \mathrm{GW}$ or more of wind power (AEE, 2006, 2011).

Italy, France and UK had a total wind power capacity installed by the end of 2010 with $5.7 \mathrm{GW}, 5.6 \mathrm{GW}$ and 5.2 GW, respectively. This same European country has increased their wind power capacity in $20 \%, 24 \%$ and $23 \%$ compared with the end of 2009. The Italian wind power sector now employs more than 28,000 people, of which some 10,000 directly. The French government set a target to achieve $25 \mathrm{GW}$ of installed wind energy capacity by 2020 , including $6 \mathrm{GW}$ of offshore wind. For Denmark, Portugal and Netherlands the total wind power capacity installed by the end of 2010 was $3.7 \mathrm{GW}$ and $2.2 \mathrm{GW}$, respectively. An interesting situation happened Denmark and Portugal have almost the same wind power capacity installed, 3,752 MW and 3,702 MW at the end of 2010. According to GWEC (2011c, p. 11) Turkey, Belgium, Poland and Sweden had presented in 2010 the biggest rates of growth in wind power capacity installed, with $66 \%, 62 \%, 53 \%$ and $39 \%$, respectively. In the United Kingdom, around 40 new wind farms were opened in 2010, totaling $962 \mathrm{MW}$ of additional capacity and taking the country's total installed wind power capacity to $5.2 \mathrm{GW}$. With $1.3 \mathrm{GW}$ of installed capacity, the UK continues to be the world's leading offshore wind market. The majority of wind farms in the UK are located in Scotland $(2.3 \mathrm{GW})$, in the North West $(1 \mathrm{GW})$ and in Wales $(0.5 \mathrm{GW})$. Only Scotland installed a third of all new wind power capacity in 2010 (0.4 GW) (GWEC, 2011a). Europe has increased 13\%, in the same period and had as wind power capacity installed more than $86 \mathrm{GW}$.

\subsection{Latin America \& Caribbean}

Latin America and Caribbean is a region of the globe with best wind resources (see Figure 1). The rest of the world has putted the eyes in Latin America because it is considered prime territory for the deployment of wind power. In the beginning the development of RE technologies have been modest, but nowadays there are no doubts that the region is an opportunity for an exponential developing of wind power industry to complement its rich hydro and biomass (and potential solar) resources, most notably in Brazil and Mexico. Brazil is the country where wind power is making the most progress; it is also the largest economy of the region. This country has many areas with tremendous potential for wind energy technology, combined with a growing electricity demand 
and solid industrial and grid infrastructure (GWEC, 2011a). We must highlight Mexico, Argentina and Brazil. These main latin countries have increased the wind power capacity installed by $156 \%, 76 \%$ and $54 \%$ respectively. Mexico had 0.518 GW, Argentina had 0.06 GW and Brazil had 0.931 GW at the end of 2010. Brazil and Mexico are in top positions in terms of wind power capacity installed at Latin America and Caribbean. Chile, Costa Rica and Caribbean these countries almost reach $0.4 \mathrm{GW}$ of wind power capacity installed. An interesting country is Chile, which had nearly $0.172 \mathrm{GW}(172 \mathrm{MW})$ of wind power in operation at the end of 2010 . The total wind power capacity installed in the Latin America and Caribbean grew by 54\% during 2010, and more than 2 $\mathrm{GW}$ of wind power capacity were installed.

\subsection{North America}

The USA wind energy market installed 5.1 GW in 2010, only about half of the 2009 market. The country now has $40.2 \mathrm{GW}$ of wind power capacity (up from $35.1 \mathrm{GW}$ at the end of 2009), thereby conceding its global leadership to China. By $76 \%$ of the American states now have utility-scale wind installations and $28 \%$ of those had more than $1 \mathrm{GW}$ installed. The leading state was Texas with more than $10 \mathrm{GW}$ of total installed capacity and wind power now produces $7.8 \%$ of the state's electricity demands. Iowa is in second place with $3.6 \mathrm{GW}$, and now receives close to $20 \%$ of its electricity from wind power, followed by California, Minnesota and Washington State (AWEA, 2011). The American manufacturing sector, meanwhile, appears to view 2010's slowdown as short-term. New component suppliers continued to enter the wind energy industry last year, and over 400 US manufacturing plants now serve the industry. Around half of the wind generation equipment deployed in the USA is now manufactured domestically. In addition, the construction pipeline for wind power is healthy, with 5.6 GW currently under construction. Given such indicators, the industry finished 2011 well ahead of 2010 numbers (GWEC, 2011a). Canada's wind energy industry took a step ahead in 2010 with the addition of 690 MW of installed wind energy capacity, ranking Canada in $9^{\text {th }}$ position globally in terms of new installed capacity and $9^{\text {th }}$ for overall cumulative installed capacity (see Figure 3 and 4). Canadian wind energy industry had done a record year in 2011 with approximately $1.2 \mathrm{GW}$ of new wind energy capacity; reflect of an investment of $\$ 3.1$ billion and creating 13,000 person-years of employment in the Canadian wind energy industry. Canada has increased the wind power capacity installed by $21 \%$ and $4 \mathrm{GW}$ of wind energy installed capacity. For the end of 2011, Canada had shown a total of wind energy installed capacity around 5.2 GW. In 2011, new wind energy projects were built and commissioned in British Columbia, Alberta, Saskatchewan, Manitoba, Ontario, Quebec, New Brunswick, and Nova Scotia (CanWEA, 2012; GWEC, 2011c). The total wind power capacity installed in the North America grew by 15\% during 2010, and more than $44 \mathrm{GW}$ of wind power capacity were installed.

\subsection{Pacific Region}

Australia wind power market at the end of 2010 had installed $1.8 \mathrm{GW}$, an increase of $10 \%$ in relation to the end of 2009. There were 52 operating wind farms in the country, mostly located in South Australia (907 MW) and Victoria (428 MW). Australia's expanded Renewable Energy Target (RET) Scheme, which entered into force in January 2010, mandates that 45 TWh or $20 \%$ of Australia's electricity supply will be sourced from renewable energy in 2020 (CEC, 2012; GWEC, 2011a). The initial goal was $12.5 \mathrm{TWh}$, and this could be gradually increased until 2020. After a good year in 2009, the rate of development in New Zealand dropped with just 8.8 MW of new wind capacity added, taking the total up to close to $506 \mathrm{MW}$, representing an increase by $2 \%$ at the end of 1010. Wind energy currently supplies just over 3\% of New Zealand's annual electricity demand. The world energy scenario has changed and it is important to highlight some its aspects. First of all, wind energy technology is more nature than ten years ago due to heavily R\&D investments and renewable energies penetration has increased (NZWEA, 2012). For the Pacific Islands had only 12 MW as total wind power capacity installed at the end of 2010, and no increase was register in the period. The total wind power capacity installed in the Pacific Region grew by $8 \%$ during 2010, and more than $2.3 \mathrm{GW}$ of wind power capacity were installed.

The total wind power capacity installed worldwide grew by $22 \%$ during 2010 , and more than $194 \mathrm{GW}$ of wind power capacity were installed. In global terms, we can say that wind market is continuing to attract new players and a significant number of new companies in Europe and Asia are developing new wind turbines to enter the market in the coming years. It is necessary to give emphasis the increasing trend of professionalism in the market. One example of this is continuous flow production; it is the need of increase output and quality and to reduce costs. Many manufacturers, including GE, REpower, Vestas and Enercon, began this process between 2003 and 2006 but had little success due to the many different wind turbine types needed to satisfy customer demands. Currently the products of the wind energy industry are more standardized; this kind of production is becoming more effective; examples of successful factories include Siemens and GE. Apart from Europe, the USA and Asia, other markets for wind energy they are still with a small market share. We must highlight, there are notable wind farm projects being planned and starting-up in the developing world. In South America, the growing markets are 
specially concentrated in Brazil, Mexico and Chile, while the African market is still dominated by Egypt and Morocco.

According to GWEC (2011a) the six regions worldwide has shown as annual installed capacity an interesting behavior (see Figure 5). In Europe, Asia and North America had demonstrated highest growth with, 86 GW (2010), 58.6 GW (2010) and 44.1 GW (2010), respectively. Also in Figure 5 we could conclude that the lowest growth was represented by Pacific Region, Latin America \& Caribbean and Africa \& Middle East with $2.3 \mathrm{GW}$ (2010), 2 GW (2010) and 1 GW (2010), respectively. For Saidur et al. (2010) there had been a remarkable increase in any type of energy demand due to the economic and technological developments worldwide. The global economy had grown $3.3 \%$ per year over the last 30 years and in the same period energy demand had increased 3.6\%. It is noticed that energy policy could help increasing wind energy industry. Oliveira and Fernandes (2011b) conclude that human evolution is closely linked to energy, since the beginning of time man has to know it and seeking it ever more on the environment.

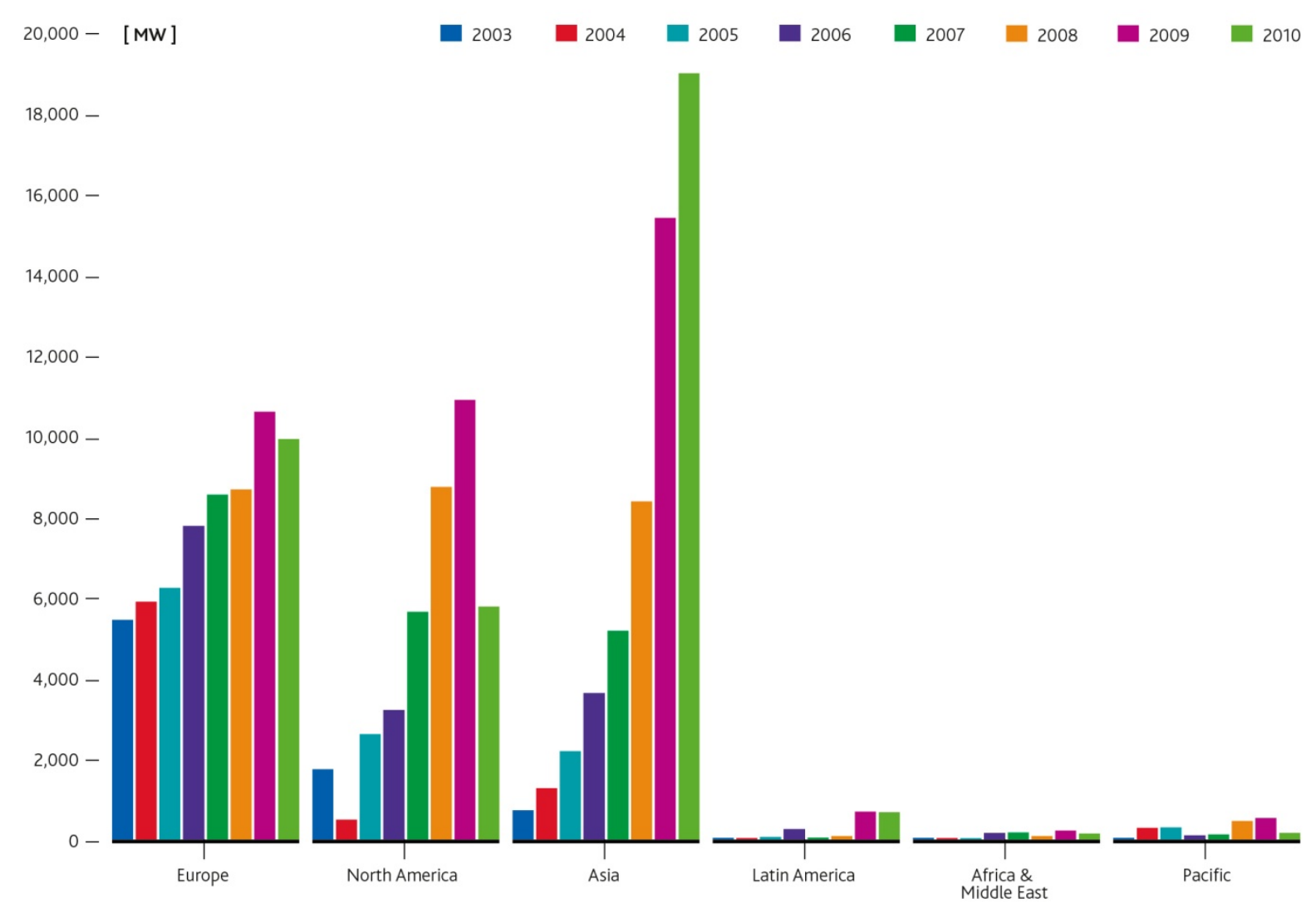

Figure 5. Annual installed capacity by region 2003-2010

Source: Global Wind Report: Annual market update 2010 (GWEC, 2011c)

\section{Wind Energy Converters Manufacturers}

In the wind energy industry, there is intense competition between the wind energy converters (WECs). Vestas and GE Energy have the largest market shares but no company controls more than $20 \%$ of the market (see Figure 6). However, there are distinct regional differences. Enercon, for example, dominates the German market with a share of $60 \%$, but at the same time the company might have difficulties maintaining its global market share if the German market slows down. The situation for GE Energy in the US and Gamesa in Spain is similar. At any rate, since there is a trend towards ever-larger models that is accompanied by increasing capital requirements, larger companies will benefit on long-term (Green Rhino Energy, 2009). When we take a look at turbine manufacturing features, Vestas one more time got the largest share (19.0\%) of the global wind market, with approximately $37 \mathrm{GW}$ (see Table 1). However, the enterprise has lost market share since 2008 and is near followed by GE Wind, whose market share was almost $18.0 \%$ in 2010. Amazingly for the first time there are also two Chinese enterprises in the top five suppliers list: Sinovel ranks sixth with 5.0\% and Goldwind is seventh with 4.0\% (see Figure 6). Although 
the wind power industry saw manufacturing volumes remain constant at their 2009 levels, manufacturing capacity increased substantially during 2010 (Note 4). Project developers were challenged by competition with natural gas prices at three-year lows (leading to reduced sales), the continued challenge of obtaining project finance, and access to transmission. Industry leaders Vestas, Gamesa, Hansen Transmissions, and GE Wind all lowered sales forecasts during 2010. Growth opportunities were focused mainly on China and other emerging markets as GE Wind supplied turbines to Brazil; Gamesa planned to triple investments in China by 2012; and Repower and Suzlon signed contracts in Turkey and Bulgaria (Note 5). Among the top 10 global manufacturing enterprises, Vestas of Denmark easily retained its number-one ranking, but Sinovel of China edged ahead of GE Wind in 2010 to take second place (Note 6) (see Figure 7).

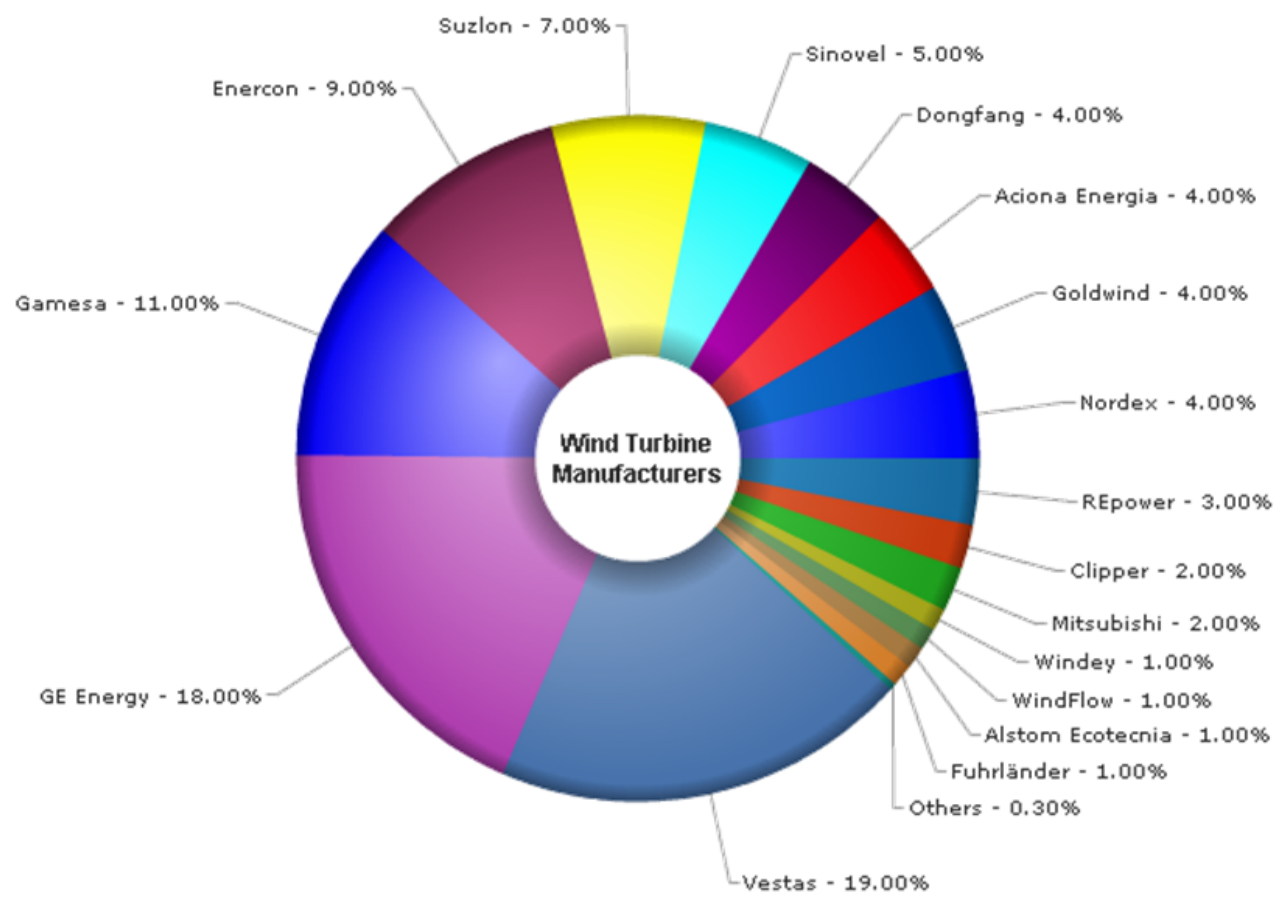

Figure 6. Wind turbine manufacturers' share. Source: Green Rhino Energy (2009)

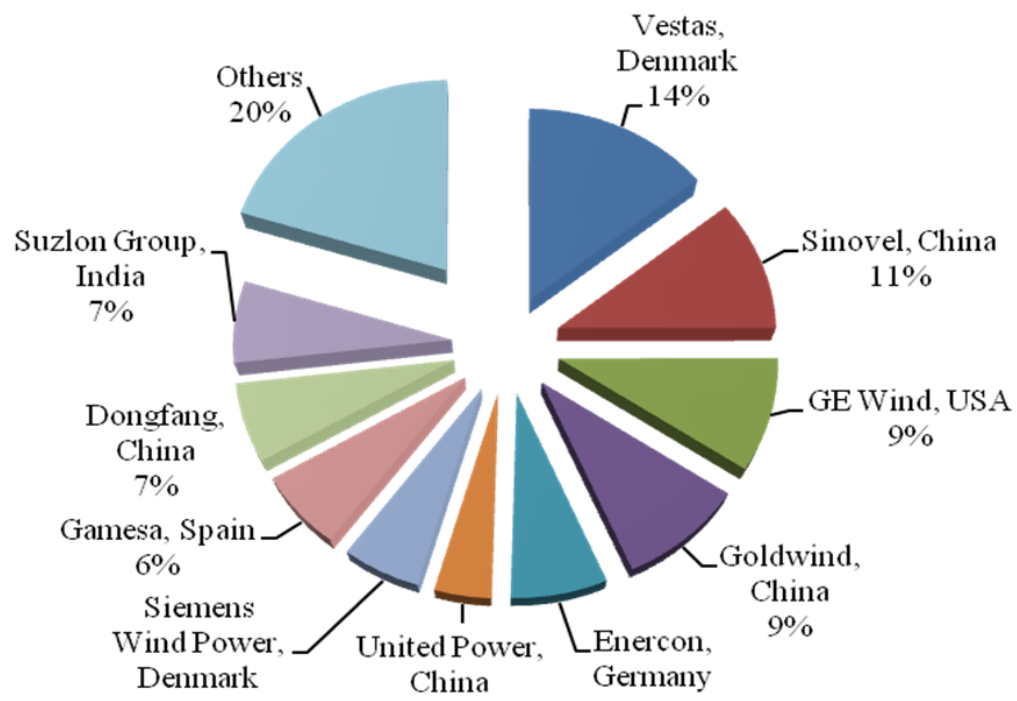

Figure 7. Market shares of top 10 wind turbine manufacturers, 2010. Source: (REN21, 2011) 
Table 1. Track record by turbine type

\begin{tabular}{lllll}
\hline & \multicolumn{2}{l}{ Installed in 2010 } & \multicolumn{2}{l}{ Accumulated installed } \\
& Number & MW & Number & MW \\
\hline V52-850 kW & 340 & 289 & 3,764 & 3,199 \\
V60-850 kW & 15 & 13 & 15 & 13 \\
V80-1.8 MW & 0 & 0 & 1,016 & 1,829 \\
V80-2.0 MW & 267 & 534 & 2,981 & 5,962 \\
V82-1.5 MW & 0 & 0 & 213 & 320 \\
V82-1.65 MW & 273 & 450 & 2,883 & 4,757 \\
V90-1.8 MW & 269 & 484 & 572 & 1,029 \\
V90-2.0 MW & 763 & 1,527 & 3,286 & 6,544 \\
V90-3.0 MW & 834 & 2,502 & 2,170 & 6,510 \\
V100-1.8 MW & 20 & 36 & 20 & 36 \\
V112-3.0 MW & 2 & 6 & 2 & 6 \\
Other & 1 & 1 & 26,511 & 6,729 \\
\hline Total & 2,784 & 5,842 & 43,433 & 36,934 \\
\hline
\end{tabular}

Source: Vestas (2011)

In China, enterprises Sinovel, Goldwind, Dongfang, and United Power saw strong growth driven by continued political and regulatory support and lower labor and manufacturing costs. Continued technology development at these enterprises also meant a smaller and closing gap in technological parity with overseas enterprises. Sinovel, for example, launched a $5 \mathrm{MW}$ turbine model in 2010 (Note 7). It appeared that industry consolidation might be on the horizon in China as a draft government policy called for narrowing the industry to far fewer than the existing 100-plus enterprises. The major developers of wind projects in China remained predominately state-owned enterprises: Longyuan, Datang, Huaneng, Huadian, CPI, and Guohua (Note 8). In Europe, industry activity focused increasingly on offshore technologies and on project development in Eastern Europe. The largest turbine to be financed so far, RePower's 6 MW model, was deployed in C-Power's 300 MW Thornton Bank project in Belgium, one of nine offshore wind farms developed in 2010 (Note 9). And Transpower's high-voltage cable transmission infrastructure is being installed in the North Sea, laying the base for German offshore connectivity by 2013. Project developers became more aggressive in Eastern Europe, for example in Ukraine, where at least 10 project developers were active in 2010 due to a new feed-in tariff (Note 10).

In the United States, 14 new turbine manufacturing plants were established in 2010 (Note 11). The U.S. industry was hampered, however, by late extension by the U.S. Congress of the Investment Tax Credit (ITC), low natural gas and electricity prices, and transmission access issues; so that project developers managed only half the number of projects they did in 2009. Leading owners of wind power projects in the United States include NextEra, Iberdrola Renewables, Horizon-EDPR, MidAmerican/PacifiCorp, and E.ON Climate \& Renewables (Note 12).

According to Markard \& Petersen (2009) it is possible to differentiate the value chain of wind energy industry into five distinct parts. The first one is the turbine manufacturing which might include the development and production of wind turbines and auxiliary equipment. The second one is the project development with its sub-tasks such as planning, licensing, leasing of the land (onshore) and wind farm construction. The third is the investment operation that is about the provision of funds for a wind farm and forth is operation that concerns about managing the business including metering and billing of electricity production and maintenance of the technical components. And finally the fifth is load management and power distribution that is always combined tasks related to balance the intermittent power supply of wind farms and distributing and selling the electricity to end consumers. It is easy to notice when the sectorial value chain is simplified as there are further tasks (e.g. environmental impact evaluation, wind farm insurance or provision of meteorological services) that also need to be taken care of.

Direct-drive turbine designs captured $18 \%$ of the global market, led by Enercon (Germany), Goldwind (China), and Hara XEMC (China). Preferred turbine sizes were $2.5 \mathrm{MW}$ in the U.K., 1.4 MW in China, and 1.2 MW in India. Globally, the average turbine size increased to 1.6 MW, up from 1.4 MW in 2007. Vestas launched the 
largest commercial turbine thus far, the dedicated offshore V164 7 MW turbine, targeting North Sea opportunities (Note 13). Li and Chen (2008b) made a comparison with geared-drive wind generator systems and concluded that most important advantages of direct-drive wind generator systems were the higher overall efficiency, reliability and availability due to no gearbox is necessary. The direct-drive generators usually have larger size, but it could not be disadvantage for the offshore wind energy applications.

The search for more productivity in the power output what forward trends for larger wind turbines, about $82 \%$ of all wind turbines installed in 2009 falling into the range of $1.5 \mathrm{MW}$ to $2.5 \mathrm{MW}$, but the growth is still slow. Wind turbines in onshore wind farms generally have a range between $2 \mathrm{MW}$ to $3 \mathrm{MW}$ in countries with a good infrastructure. Although, larger wind farms with smaller turbines (up to 1.5 MW) are under development or have been installed in areas with poorer infrastructure. The REpower 6M and the Enercon E-126 are particularly well-known. The $6 \mathrm{M}$ has a rated capacity of $6.15 \mathrm{MW}$ while the Enercon E-126 is available with $6 \mathrm{MW}$ of rated capacity (Wiese et al., 2010).

Table 2. Top 10 globally wind turbine manufacturers of 2009, currently used generator concepts and power ranges

\begin{tabular}{llll}
\hline Manufacturer & Concept & Rotor diameter & Power range \\
\hline Vestas (Denmark) & DFIG & $52-90 \mathrm{~m}$ & $850 \mathrm{~kW}-3 \mathrm{MW}$ \\
& GFC PM & $112 \mathrm{~m}$ & $3 \mathrm{MW}$ \\
\hline General Electric (US) & DFIG & $70.5-82.5 \mathrm{~m}$ & $1.5 \mathrm{MW}$ \\
& GFC PM & $100 \mathrm{~m}$ & $2.5 \mathrm{MW}$ \\
& DD PM & $110 \mathrm{~m}$ & $4.0 \mathrm{MW}$ \\
\hline Sinovel (China) & DFIG & $60-113 \mathrm{~m}$ & $1.5-3 \mathrm{MW}$ \\
\hline Enercon (Germany) & DD EE & $33-126 \mathrm{~m}$ & $300 \mathrm{~kW}-7.5 \mathrm{MW}$ \\
\hline Goldwind (China) & DD PM & $70-100 \mathrm{~m}$ & $1.5 \mathrm{MW}-2.5 \mathrm{MW}$ \\
\hline Gamesa (Spain) & DFIG & $52-97 \mathrm{~m}$ & $850 \mathrm{~kW}-2 \mathrm{MW}$ \\
& GFC PM & $128 \mathrm{~m}$ & $4.5 \mathrm{MW}$ \\
\hline Dongfang (China) & DFIG & - & $1-2.5 \mathrm{MW}$ \\
\hline Suzlon (India) & CS & $52-88 \mathrm{~m}$ & $600 \mathrm{~kW}-2.1 \mathrm{MW}$ \\
\hline Siemens (Germany) & GFC IG & $82-107 \mathrm{~m}$ & $2.3-3.6 \mathrm{MW}$ \\
& DD & $101 \mathrm{~m}$ & $3 \mathrm{MW}$ \\
\hline Repower (Germany) & DFIG & $82-126 \mathrm{~m}$ & $2-6 \mathrm{MW}$ \\
\hline
\end{tabular}

Source: Polinder (2011). CS: constant speed with gearbox and induction generator, possibly with extended slip or two speeds; DFIG: variable speed with gearbox, doubly-fed induction generator and partly rated converter; DD EE: variable speed direct-drive synchronous generator with electrical excitation and full converter; DD PM: variable speed direct-drive permanent-magnet generator and full converter; GFC PM: variable speed with gearbox, permanent-magnet generator and full converter; GFC IG: variable speed with gearbox, induction generator and full converter.

The power output of a wind turbine is roughly proportional to the rotor area, so fewer larger rotors at higher towers use the wind resources more efficiently than more numerous, smaller wind turbines. The biggest commercial wind turbines today are 5-6 MW units with a rotor diameter of up to $126 \mathrm{~m}$. Every five years wind turbines have doubled in size approximately, but this rate seems to be slow for onshore turbines, due to operational and installation constraints. The expected lifetime of a commercial wind turbine currently is $20-25$ years. Lifetime spans may stretch as the technology continues to mature. However, due to the youth of the industry, as we know today, and the re-powering of wind farms with the updated turbine technology, few turbines have been around long enough to test this consideration. Due to extensive testing and certification, the reliability of wind turbines - the proportion of the time they are technically available for operation - is approximately $99 \%$ (Furkan, 2011). During the last ten years power electronics have represented a key factor in the evolution of wind turbines towards more efficient 
wind energy capture, better quality of voltage output, better grid integration, etc. Efficiency is an important issue for wind turbines when comparing different systems because losses reduce the average power produced by the wind energy converter and, so on, they reduce incomes (Amirat \& Benbouzid, 2007, p. 28). The Table 2, it is shown a list of top 10 globally wind turbine manufacturers in 2009 with its currently used generator concepts and power ranges. The Table 2 starts with describing the most commonly used generator systems in wind turbines manufacturers' leader worldwide. Each manufacturer is market-oriented and size and concept differ during the period of time. The most important trend in the marketplace is the progressive increase in the size of commercial wind turbines as a result of a bigger power output search. The average wind turbine size has thus increased by about $12 \%$ per year over the last decade (Hansen \& Hansen, 2007).

\section{Economic Impacts from Wind Energy Industry}

Wind power plants installations can create jobs in a country where local economies are often dependent on local business activities. Local jobs refer to construction-related activities; operation and maintenance of the facility after it is constructed, and jobs induced by the money addition in the local economy by the temporary workers. Lantz and Tegen (2008) made some studies about the variables affecting in an economic development process by wind energy activities. Lantz and Tegen (2008) states that "creating policies to ensure maintenance materials are supplied by in-state business and that the local labor force is trained to perform wind turbine maintenance is also likely to have a large impact for wind power plants operating for 20 or more years". The maximization of economic benefits by wind energy development is linked to the improvement of related in-state businesses and trained labor force.

Greater energy independence, improved environmental benefits from reduced greenhouse gas emissions and positive economic impacts have been appointed as the main three main reasons for investing on wind energy industry. When we have to face our climate responsibilities and the opportunity to build a low-carbon economic base, job creation is an especially question to discuss about. The development of indigenous sources of renewable energy technology, as wind power, will forward the creation of more jobs locally than business as usual' fossil-fuel economies of the last century (Engel \& Kammen, 2009). The focus on finding solutions for mitigating global warming has resulted in renewable energy technologies gaining importance. Improvements accomplished in technology resulted in a fast growth in wind power worldwide. Among the renewable energy technologies, wind power is one of the fastest growing technologies globally at an average annual growth rate of more than $26 \%$ since 1990 (Resch et al., 2008).

According to World Wind Energy Association (WWEA, 2011) by the end of the year 2010, about 670,000 people were employed worldwide directly and indirectly in the many areas in the wind industry. During the last five years, the number of jobs almost tripled, from 235,000 in 2005. There is an increasing demand for a very broad range of jobs, from engineers, skilled workers to managers, financial, environmental and legal experts. One of the positive aspects of the wind energy industry is the impact on employs, but few studies have systematically dealt with this matter (Blanco \& Rodrigues, 2009). The development of renewable energy industry has become a way to accomplish environmental objectives and a long way of increasing energy self-sufficiency and employment in general (Connor, 2003; Dincer, 2000; Hillebrand, Buttermann, Behringer, \& Bleuel, 2006; Laitner, Bernow, \& DeCicco, 1998; Moreno \& López, 2008; Thothathri, 1999). The adoption of renewable energies technologies represent an opportunity to reduce energy dependence, reduce the emission of $\mathrm{CO}_{2}$ and create new employs and revenues. The engagement of local economic agents is extreme necessary for the future development of RE technologies, especially in regions whose industrial activity mix was based on traditional energy sources. Wind energy industry in Europe is a predominantly male business with $78 \%$ employment, where men represent the majority of the labor force in fields of construction, production and engineering (Moreno \& López, 2008).

The development of wind power can create new opportunities for more domestic jobs per currency invested and/or per kilowatt-hour produced than fossil fuel power generation. Manufacturing of wind power utilities and equipment, constructing and installing the wind projects, and operating and maintaining the projects over their lifetime usually create direct jobs (Lewis \& Wiser, 2007). The wind energy industry has become a major job generator globally: within only three years, the wind industry worldwide almost doubled the number of jobs from 235,000 in 2005 to 440,000 in the year 2008 (see Figure 8). These 440,000 employees in the wind energy industry worldwide, most of them highly skilled jobs, have been contributing to the generation of $260 \mathrm{TWh}$ of electricity (WWEA, 2011). 


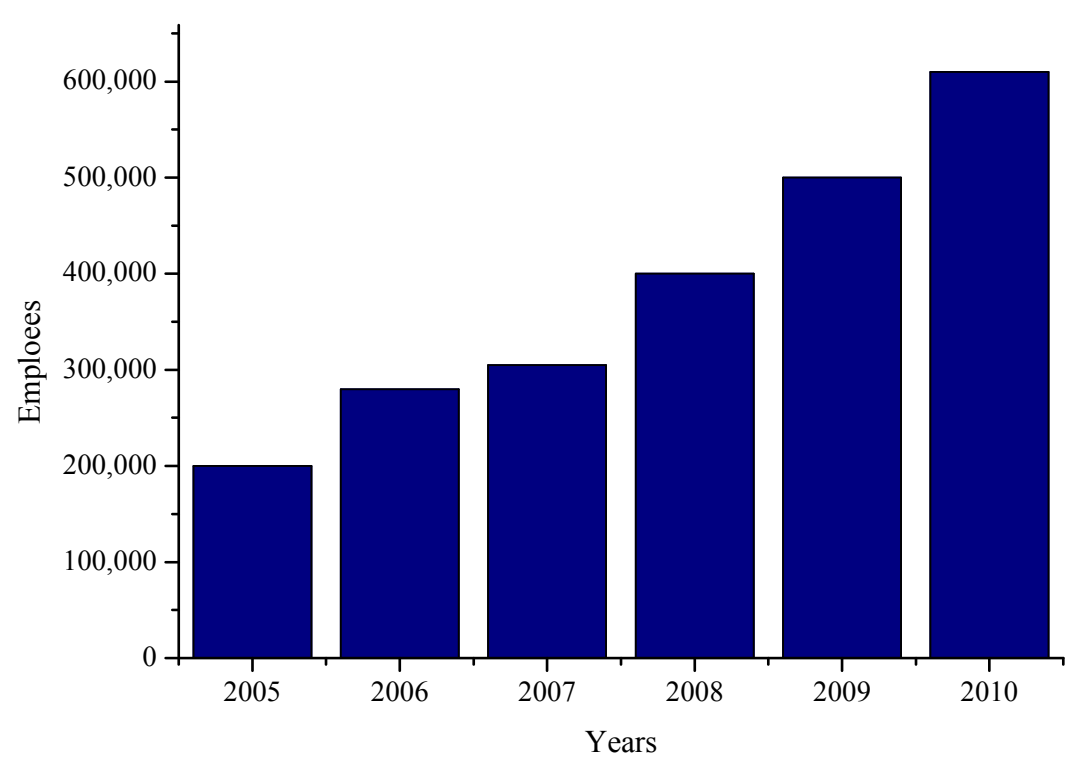

Figure 8. Green jobs on wind energy sector worldwide. Source: WWEA (2011)

Wind energy industry represents an attractive source of employment worldwide. Activities as construction, O\&M, legal and environmental studies are best driven at local level; we can notice a positive correlation between the location of the wind farm and the number of jobs it creates. The location of a wind farm determine where can be located large manufacturing centers, however, microeconomic factors such as, skilled labor force, easy access roads, grids infrastructure and regional and municipal authorities have a role to play. Another relevant issue is that wind energy employment is following the opposite trend to the general energy industry, particularly coal extraction and electricity generation, and measures that encourage the transfer of workers from general energy industry to wind energy activities could be highly beneficial from both social and economic aspects (Blanco \& Rodrigues, 2009; Thothathri, 1999).

According to Hamilton \& Liming (2010) the process of getting energy from the wind into the home is so complex, in business terms, that is why it involves many players simultaneously. A modern and commercial wind turbine consists of an estimated 8,000 parts. Turbines must be designed, built, transported, and erected before they can start producing energy. As we had said the chain of wind industry can be classified into three major phases: manufacturing, project development, and operation and maintenance. A wind energy successful project, each of these phases overlap and there is substantial communication among players in all these three phases. The manufacturing sector hosts most of the jobs, followed by construction, and operation and maintenance. However, in the case of new wind farms forward the repower process, for manufacturers can take advantage of returns to scale. Figure 9 shows the distribution of jobs in American wind power industry in 2010.

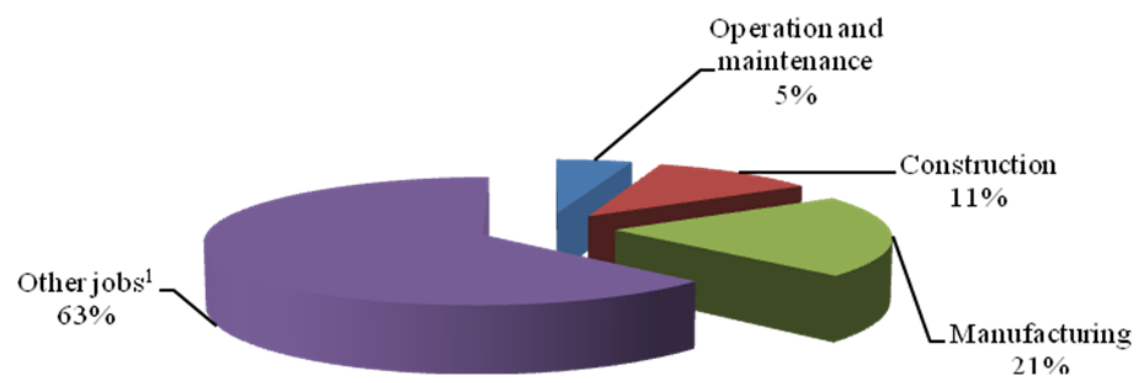

Figure 9. Jobs in wind power, 2009. Source: Hamilton \& Liming (2010)

(1) "Other jobs" includes the following: some manufacturing, parts-related services, financial and consultant services, developers and development services, contracting and engineering services, and transportation and logistics. 
Large wind turbines are made of complex pieces of machinery designed and built by companies known as Original Equipment Manufacturers (OEMs). Most of OEMs are large transnational corporations for which wind turbine manufacturing phase is only a small piece of their global business. Wind farm development is a challenging process that usually takes several years from conception to construction. The beginning of this process is the selection of an appropriate site. This step involves a great number of factors, such as wind speed and frequency, availability of area, ground constitution for supporting the weight - often more than $1,000 \mathrm{t}-$ of turbine structures, environmental concerns — such as local avian populations and the feasibility of transporting large turbine components to the site chosen. In the phase of project development also has many legal and financial issues such as contract development and financing. All of this work representing the pre-operational phase of the wind energy project. The self-running of wind energy projects is a way it works by itself with little need for human supervision (remote controlling). Energy companies employ monitors, either locally or remotely, to observe energy flows and report technicians of any problems. All wind farms employ local workers, but remote monitoring of wind turbines can allow for a cost-effective way to ensure that the wind turbine (wind farm) is working most efficiently as possible and that local technicians are alerted to any potential problems advised (Ayee, Lowe, \& Gereffi, 2009).

The initial spending on the construction and operation phases of the wind farm has a second and economic effect, usually referred as "indirect impacts". Indirect impacts during the construction phase representing the changes on relations inter-industry from the direct final demand changes which includes construction spending on materials, wind farm equipment; other purchases of related-goods and offsite services. And increase in some final product represent an also increase in its components to produce it as well as an increase in the economic activity at local site (Goldberg, Sinclair, \& Milligan, 2005). Indirect impacts reflect on all supply chain component impacts/manufacturing-related activities; therefore, the final phase of turbine assembly process, which includes gearbox assembly, blade production, and steel rolling are all included under the construction period indirect impacts category. Also the manufacturers of turbine parts such as bearing producers, steel producers, and gear producers are also in this same category. Indirect impacts during operating years refer to the changes in inter-industry purchases resulting from the direct final demand changes (Lantz \& Tegen, 2008).

Landowners who lease their land to wind developers benefit from having a stable source of revenues. This option is usually greater than that from ranching or farming if we compare on a per acre basis, the revenue receive from leasing their land by wind developers. Landowners can be compensated in a variety of ways: option payments, construction disturbance or installation payments, land leases, and/or royalties. While royalty is a percentage of gross revenues received by the wind farm owner from the sale of power (Pedden, 2006).

According to Goldberg et al. (2005) it is possible to classify the total effect of developing a wind power plant into three types of impacts. They can be defined as direct effect, indirect effect, and induced effect:

1. Direct effect: they are general on-site or immediate effects created by expenditures. In constructing a wind power plant, it refers to the on-site jobs of the contractors and crews hired to construct the plant. It also includes the jobs at the turbine manufacturing plants and the jobs at the tower and blade factories.

2. Indirect effect: It refers to the increase in local economic activity that happens when a contractor, vendor or manufacturer receives payment for goods or services and in turn is able to pay others who support their business - economy cycle. For instance, this impact includes the banker who finances the contractor; the accountant who keeps the contractor's books; and the steel mills and electrical manufacturers and other suppliers that provide the necessary materials on-site.

3. Induced effect: It is a reflect effect and usually refers to the change in wealth and income that is induced by the spending of those economic agents (workers, companies, public services, etc.) directly and indirectly employed by the wind project. This would include spending on food, clothing, or day care by those directly or indirectly employed by the project, retail services, public transit, utilities, cars, oil, property \& income taxes, medical services, and insurance, for example.

\section{Conclusions}

Related to wind resources worldwide, many studies deal with wind speeds geographical distribution and most of them converge that characteristic parameters of the wind profile, orography, topography and local wind flow and measurement of the wind speed are very necessary in wind resource evaluation for a successful and safe application of wind turbines (de Castro, Mediavilla, Miguel, \& Frechoso, 2011). The potential availability of wind power can change over time and among locations. This variation is not only caused by the resource characteristics (wind regime and profile, soil, humidity, etc.) but also by geographical (land use and land cover), techno-economic (scale, labor cost, inflation, time horizon, etc.) and institutional (policy regime, legislation 
specialized) factors. Some of these factors cannot or can only approximately be quantified or estimated.

In respect to global wind energy situation we can say about 2010 was a tough year for wind energy industry, and although cumulative market growth was around $22.5 \%$, the annual market decreased for the first time in the last twenty year. The financial crisis in medium term brought some consequences and the global economy had to slowdown, and very low orders in OECD countries at the end of 2008 and the beginning of 2009 made themselves felt in the 2010 installation totals, particularly in the USA. Amazingly approximately $36 \mathrm{GW}$ of new wind power capacity was added around the world last year, and for once the majority of that new capacity was in developing countries and emerging economies; driven mainly by the booming wind sectors in China and India, but also with strong growth in Latin America, where we believe that macroeconomic situation and wind resource-rich will make the wind energy industry jumps much forward in those regions which we have been waiting for and expecting for so many years (GWEC, 2011c).

The growth of wind power outside of the OECD has been essential driven by the continuing boom in China, which is now the top country in installed wind power capacity in the world (see Figures 3, 4, 7 and Table 2). There is also a great change of attitude by government towards wind power in many countries. First of all wind technology was considered too expensive by many developing country energy planners just a couple of years ago, the progressive success of the technology in much more countries have changed that attitude to one of dramatically increased knowledge about wind energy and how could wind energy technology improve the country's power mix.

Economic impacts from wind energy industry are clearly positive in a macroeconomic terms, because its impacts on employment, incomes and taxes and production of goods and services in general. First of all, it is necessary to emphasize that wind energy industry represent an important source of employment in many countries in the globe. There are some activities like operation and maintenance (O\&M), research and development (R\&D), manufacturing and construction which are able to create jobs in wind industries.

The electric power industry is a strongly regulated industry and, in the case of RE technologies, the role of governments' incentive to bring these young technologies (related to fossil fuel technologies) to market adds to the importance of politics. Looking at the growth of wind turbine capacity over the past ten years, some conclusions can be taken. Among all renewable energies, wind energy is certainly the one that is closest to making the transition from niche to mass market. It is strongly linked with long-term prosperity. For Pablo (2008) investment explains the productive capacity of an economy. Investments made in the renewable energy industry have in addition a strong influence on the degree of dependence among economies, their competitiveness, sustainability, and on all kinds of environmental issues including climate change.

\section{References}

AEE. (2006). Análisis y Diagnóstico de la Situación de la Energía Eólica en Espanã. Datos Básicos de la Eólica en España. Retrieved November 27, 2009, from http://www.aeeolica.es/contenidos.php?c_pub=101

AEE. (2011). Datos básicos de la eólica en España. Retrieved March 14, 2011, from http://www.aeeolica.es/contenidos.php?c_pub=101

Ahmed, A. S. (2011). Analysis of electrical power form the wind farm sitting on the Nile River of Aswan, Egypt. Renewable \& Sustainable Energy Reviews, 15(3), 1637-1645. http://dx.doi.org/10.1016/j.rser.2010.11.024

Amirat, Y., \& Benbouzid, M. (2007). Survey paper Generators for Wind Energy Conversion Systems: State of the Art and Coming Attractions. J. Electrical Systems, 3(1), 26-38.

Archer, C. L., \& Jacobson, M. Z. (2005). Evaluation of global wind power. J. Geophys. Res, 110, 1-20. http://dx.doi.org/10.1029/2004JD005462

Arslan, O. (2010). Technoeconomic analysis of electricity generation from wind energy in Kutahya, Turkey. Energy, 35(1), 120-131. http://dx.doi.org/10.1016/j.energy.2009.09.002

AWEA. (2011). U.S. Wind Industry Market Reports. Retrieved November 15, 2011, from http://www.awea.org/learnabout/publications/reports/AWEA-US-Wind-Industry-Market-Reports.cfm

Ayee, G., Lowe, M., \& Gereffi, G. (2009). Wind Power: generating electricity and employment in Manufacturing climate solutions: carbon-reducing technologies and US jobs. Durham, NC: Duke University. Center on Globalization Governance and Competitiveness.

Bilgili, M., Yasar, A., \& Simsek, E. (2011). Offshore wind power development in Europe and its comparison with onshore counterpart. Renewable \& Sustainable Energy Reviews, 15(2), 905-915. http://dx.doi.org/10.1016/j.rser.2010.11.006 
Blanco, M. I., \& Rodrigues, G. (2009). Direct employment in the wind energy sector: An EU study. Energy Policy, 37(8), 2847-2857. http://dx.doi.org/10.1016/j.enpol.2009.02.049

Brown, L. R. (2003). Wind Power Is Set to Become World's Leading Energy Source. HUMANIST-BUFFALO-, 63(5), 5-5.

CanWEA. (2012). Canada moves to 6th place globally for new installed wind energy capacity in 2011. Retrieved March 5th, 2012, from http://www.canwea.ca

CEC. (2012). Clean Energy Australia 2010. Retrieved January 16, 2012, from http://www.cleanenergycouncil.org.au

Connor, P. M. (2003). UK renewable energy policy: a review. Renewable and Sustainable Energy Reviews, 7(1), 65-82. http://dx.doi.org/10.1016/S1364-0321(02)00054-0

de Castro, C., Mediavilla, M., Miguel, L. J., \& Frechoso, F. (2011). Global wind power potential: Physical and technological limits. Energy Policy, 39(10), 6677-6682. http://dx.doi.org/10.1016/j.enpol.2011.06.027

Dincer, I. (2000). Renewable energy and sustainable development: a crucial review. Renewable and Sustainable Energy Reviews, 4(2), 157-175. http://dx.doi.org/10.1016/S1364-0321(99)00011-8

Elliott, D. (2002). Assessing the world's wind resources. Paper presented at the Power Engineering Society Winter Meeting, 2002. IEEE.

Engel, D., \& Kammen, D. M. (2009). Green jobs and the clean energy economy. Copenhagen: Retrieved from http://us-cdn.creamermedia.co.za/assets/articles/attachments/21589_greenjobs.pdf

EWEA. (2012). Wind in power. 2011 European statistics. Retrieved February 13, 2012, from http://www.ewea.org/fileadmin/ewea_documents/documents/publications/statistics/Stats_2011.pdf

Furkan, D. (2011). The analysis on wind energy electricity generation status, potential and policies in the world. Renewable and Sustainable Energy Reviews, 15(9), 5135-5142. http://dx.doi.org/10.1016/j.rser.2011.07.042

GACGC. (2004). World in Transition - Towards Sustainable Energy Systems. Retrieved October 14, 2009, from http://www.wbgu.de/wbgu_jg2003_engl.pdf

Gökçek, M., \& Genç, M. S. (2009). Evaluation of electricity generation and energy cost of wind energy conversion systems (WECSs) in Central Turkey. Applied Energy, 86(12), 2731-2739. http://dx.doi.org/10.1016/j.apenergy.2009.03.025

Goldberg, M., Sinclair, K., \& Milligan, M. (2005). Job and economic development impact (JEDI) model: A user-friendly tool to calculate economic impacts from wind projects. Paper presented at the 2004 Global WINDPOWER Conference, Chicago, Illinois.

Goode, P. R., Qiu, J., Yurchyshyn, V., Hickey, J., Chu, M. C., Kolbe, E., . . Koonin, S. E. (2001). Earthshine observations of the Earth's reflectance. Geophys. Res. Lett., 28(9), 1671-1674. http://dx.doi.org/10.1029/2000GL012580

Green Rhino Energy. (2009). Wind Energy Market and Industry. Retrieved November 14, 2010, from http://www.greenrhinoenergy.com/renewable/wind/wind_market.php

GWEC. (2011a). Global Wind Statistics 2010. Retrieved February 2nd, 2011, from http://www.gwec.net/fileadmin/documents/Publications/GWEC_PRstats_02-02-2011_final.pdf

GWEC. (2011b). Global Wind Energy Outlook 2010. Retrieved February 26, 2011, from http://www.gwec.net/fileadmin/documents/Publications/GWEO\%202010\%20final.pdf

GWEC. (2011c). Global Wind Report: Annual market update 2010. Retrieved April 10, 2011, from http://www.gwec.net/fileadmin/documents/Publications/Global_Wind_2007_report/GWEC\%20Global\%20 Wind\%20Report\%202010\%20low\%20res.pdf

Hamilton, J., \& Liming, D. (2010). Careers in Wind Energy: Bureau of Labor Statistics.

Hansen, A. D., \& Hansen, L. H. (2007). Wind turbine concept market penetration over 10 years (1995-2004). Wind Energy, 10(1), 81-97. http://dx.doi.org/10.1002/we.210

Herbert, G. M. J., Iniyan, S., Sreevalsan, E., \& Rajapandian, S. (2007). A review of wind energy technologies. Renewable and Sustainable Energy Reviews, 11(6), 1117-1145. http://dx.doi.org/10.1016/j.rser.2005.08.004

Hillebrand, B., Buttermann, H. G., Behringer, J. M., \& Bleuel, M. (2006). The expansion of renewable energies and employment effects in Germany. Energy Policy, 34(18), 3484-3494. 
http://dx.doi.org/10.1016/j.enpol.2005.06.017

Laitner, S., Bernow, S., \& DeCicco, J. (1998). Employment and other macroeconomic benefits of an innovation-led climate strategy for the United States. Energy Policy, 26(5), 425-432. http://dx.doi.org/10.1016/S0301-4215(97)00160-2

Lantz, E., \& Tegen, S. (2008, June 1-4). Variables affecting economic development of wind energy. Paper presented at the WINDPOWER 2008, Houston, Texas.

Lewis, J. I., \& Wiser, R. H. (2007). Fostering a renewable energy technology industry: An international comparison of wind industry policy support mechanisms. Energy Policy, 35(3), 1844-1857. http://dx.doi.org/10.1016/j.enpol.2006.06.005

Li, H., \& Chen, Z. (2008b). Overview of different wind generator systems and their comparisons. Renewable Power Generation, IET, 2(2), 123-138. http://dx.doi.org/10.1049/iet-rpg:20070044

Lu, X., McElroy, M. B., \& Kiviluoma, J. (2008). Global potential for wind-generated electricity. Paper presented at the the National Academy of Sciences.

Maddaloni, J. D. (2005). Techno-economic Optimization of Integrating Wind Power into Constrained Electric Networks. Master of Applied Science, University of Victoria, Victoria, BC.

Manwell, J., McGowan, J., \& Rogers, A. (2002). Wind energy explained: Theory, design and application. England: John Willey \& Sons. http://dx.doi.org/10.1002/0470846127

Marafia, A. H., \& Ashour, H. A. (2003). Economics of off-shore/on-shore wind energy systems in Qatar. Renewable Energy, 28(12), 1953-1963. http://dx.doi.org/10.1016/S0960-1481(03)00060-0

Markard, J., \& Petersen, R. (2009). The offshore trend: Structural changes in the wind power sector. Energy Policy, 37(9), 3545-3556. http://dx.doi.org/10.1016/j.enpol.2009.04.015

Moreno, B., \& López, A. J. (2008). The effect of renewable energy on employment. The case of Asturias (Spain). Renewable and Sustainable Energy Reviews, 12(3), 732-751. http://dx.doi.org/10.1016/j.rser.2006.10.011

NZWEA. (2012). Wind generation in New Zealand. Retrieved January 15, 2012, from http://windenergy.org.nz

Oliveira, W. S. (2010b). Avaliação e gestão de projectos de energia eólica onshore. Master in Sustainable Energy Systems, University of Aveiro, Aveiro. Retrieved from http://hdl.handle.net/10773/5007

Oliveira, W. S., \& Fernandes, A. J. (2011b). Renewable Energy: Impacts upon the Environment, Economy and Society. [Review]. Cyber Journals: Multidisciplinary Journals in Science and Technology, Journal of Selected Areas in Renewable Energy (JRSE), 2(11), 7-17.

Pablo, F. (2008). Renewable energy in a market-based economy: How to estimate its potential and choose the right incentives. Renewable Energy, 33(8), 1768-1774. http://dx.doi.org/10.1016/j.renene.2007.09.017

Pedden, M. (2006). Analysis: Economic impacts of wind applications in rural communities. Colorado: National Renewable Energy Laboratory. Retrieved from http://www.osti.gov/bridge

Petersen, E. L., Mortensen, N. G., Landberg, L., Højstrup, J., \& Frank, H. P. (1998b). Wind power meteorology. $\begin{array}{lllll}\text { Part II: siting and models. Wind Energy, } 1(2), & 55-72 .\end{array}$ http://dx.doi.org/10.1002/(SICI)1099-1824(199812)1:2<55::AID-WE5>3.0.CO;2-R

Polinder, H. (2011, 24-29 July 2011). Overview of and trends in wind turbine generator systems. Paper presented at the Power and Energy Society General Meeting, 2011 IEEE.

Pryor, S. C., \& Barthelmie, R. J. (2010). Climate change impacts on wind energy: A review. Renewable and Sustainable Energy Reviews, 14(1), 430-437. http://dx.doi.org/10.1016/j.rser.2009.07.028

REN21. (2011). Renewables 2011 Global Status Report. Paris: Retrieved from http://www.ren21.net/Portals/97/documents/GSR/REN21_GSR2011.pdf.

Resch, G., Held, A., Faber, T., Panzer, C., Toro, F., \& Haas, R. (2008). Potentials and prospects for renewable energies at global scale. Energy Policy, 36(11), 4048-4056. http://dx.doi.org/10.1016/j.enpol.2008.06.029

RETScreen ${ }^{\circledR}$ International Clean Energy Decision Support Centre. (2009). Wind energy project analysis. Software manual, Chapter 2. Retrieved June 12, 2009, from www.retscreen.net

Rosa, A. V. (2009). Fundamentals of Renewable Energy Processes (2nd ed.). UK: Elsevier.

Saidur, R., Islam, M. R., Rahim, N. A., \& Solangi, K. H. (2010). A review on global wind energy policy. Renewable \& Sustainable Energy Reviews, 14(7), 1744-1762. http://dx.doi.org/10.1016/j.rser.2010.03.007 
Thothathri, R. (1999). The wind brought jobs and prosperity. New Energy, 4, 28-30.

Vestas. (2011). Annual report 2010 (pp. 152). Copenhagen: Vestas Wind Systems A/S.

Wiese, A., Kleineidam, P., Schallenberg, K., Ulrich, A. J., \& Kaltschmitt, M. (2010). Renewable power generation - a status report. Renewable Energy Focus, 11(4), 34-39, $42-45$.

Wiser, R. H., \& Hand, M. (2010a). Wind Power: How Much, How Soon, and At What Cost?

WWEA. (2011). World Wind Energy Report 2010. Retrieved April 11, 2011, from http://www.wwindea.org/home/images/stories/pdfs/worldwindenergyreport2010_s.pdf

\section{Notes}

Note 1: Wind classes determine which turbine is suitable for the normal wind conditions of a particular site. They're mainly defined by the average annual wind speed (measured at the turbine's hub height), the speed of extreme gusts that could occur over 50 years, and how much turbulence there is at the wind site. The three wind classes for wind turbines are defined by an International Electrotechnical Commission standard (IEC), and correspond to high, medium and low wind. For more information, please see http://www.iec.ch/.

Note 2: The amount of energy reflected by a surface is called albedo. Albedo is measured on a scale from zero to one (or sometimes as a percent). For more explanation, please see Goode et al. (2001).

Note 3: It is the study of the formation and relief of mountains and can more broadly include hills, and any part of a region's elevated terrain. For more information, please see Petersen, Mortensen, Landberg, Højstrup, \& Frank (1998b).

Note 4: For more details, please see Steve Sawyer, Global Wind Energy Council (GWEC), personal communication with REN21, 19 April 2011.

Note 5: According to Rikki Stancich, "2010 in Review: Peaks and Troughs for the International Wind Energy Sector, ” WindEnergyUpdate.com, 6 December 2010.

Note 6: Note that Suzlon Energy (IND) and Repower (GE) are listed as a Suzlon Group for the first time in BTM Consult's World Market Update. Rankings and data in Figure 13 from BTM Consult - A Part of Navigant Consulting, World Market Update 2010 (Ringkøbing, Denmark: 2011), provided by Birger Madsen, BTM Consult, personal communication with REN21, March and June 2011. Note that the total quantity of capacity supplied exceeds $100 \%$ of the global market because some capacity was in transit or under construction and not yet commissioned at year-end. Data were adjusted for Figure 7 such that the sum of shares supplied totals $100 \%$.

Note 7: Sinovel, "SL5000,” www.sinovel.com/en/procducts.aspx?ID=148, viewed 19 April 2011.

Note 8: Shi Pengfei, Chinese Wind Energy Association and GWEC, personal communication with REN21, April 2011.

Note 9: Repower Corporation, "REpower: 295 MW Contract Signed for Thornton Bank Offshore Wind Farm," press release (Hamburg/Antwerp: 25 November 2010).

Note 10: Vanya Drogomanovich, “Can Wind Turn Ukraine's Orange Revolution Green?" Bloomberg New Energy Finance Monthly Briefing, October 2010, p.12.

Note 11: American Wind Energy Association (AWEA), Wind Energy Weekly, 8 April 2011.

Note 12: Emerging Energy Research, North America Wind Plant Ownership Rankings 2010: Trends and Review (Cambridge, MA: 31 March 2011).

Note 13: See Chris Red, "Wind Turbine Blades: Getting Bigger and Bigger", CompositesWorld.com, viewed 20 June 2011. 